\title{
Credibility and the design of regulatory agencies in Brazil*
}

\author{
Credibilidade e o projeto de agências \\ reguladoras no Brasil
}

BERNARDO MUELLER**

CARLOS PEREIRA***

\begin{abstract}
RESUMO: Neste artigo, modelamos o processo de planejamento de agência reguladora, com foco no papel da credibilidade. O governo é limitado no sentido de que deve criar instituições reguladoras que lhe permitam comprometer-se a não expropriar administrativamente investidores. O modelo explica tanto a preferência do chefe da agência escolhida pelo governo quanto o nível ótimo de controle estatutário. Argumentamos que no Brasil essa troca entre credibilidade e controle das agências é essencial para entender as instituições reguladoras específicas que foram escolhidas. Os resultados estáticos comparativos são obtidos para examinar como as mudanças em algumas variáveis-chave afetam o planejamento das agências, fornecendo-nos um conjunto de hipóteses para comparar o projeto de cinco agências diferentes criadas para regular indústrias com características muito diferentes. Embora essas agências tenham sido criadas inicialmente com projetos muito semelhantes, espera-se que elas evoluam de maneiras que estejam de acordo com nossa teoria.

PALAVRAS-CHAVE: Regulamentação; credibilidade; agências reguladoras; informações assimétricas.
\end{abstract}

ABSTRACT: In this paper we model the process of regulatory agency design, focusing on the role of credibility. The government is constrained in the sense that it must create regulatory institutions that allow it to commit to not administratively expropriate investors. The model

\footnotetext{
* Financial support from CNPq is acknowledged by Bernardo Mueller. We would like to thank participants at the following conferences for comments: Seminário sobre Regulação de Mercados - UFBA, August 2000; 4th Annual Conference of the International Society for New Institutional Economics ISNIE, Tübingen, Germany, September 2000; ANPEC - Campinas, December 2000; II Encontro da Sociedade Brasileira da Nova Economia Institucional, Campinas, March 2001; First Annual Oxford Petrobras Conference, Oxford University, June 2001; ECPR Conference at the University of Kant at Canterbury, 6-8 September 2001. We are grateful to Marcus Melo and Nilson Costa for sharing data with us about the design regulatory agencies in Brazil. We also are grateful for the reviewers'comments.

* Assistant Professor, Department of Economics, Universidade de Brasilia - UNB, Brasília/DF, Brasil. E-mail: bmueller@unb.br; Orcid 0000-0002-0268-8377.

$* * *$ Research Fellow in Politics, Centre for Brazilian Studies - University of Oxford, United Kingdom. E-mail: pereirace@uol.com.br; Orcid: 0000-0002-8978-1493.
} 
explains both the preference of the agency head chosen by the government as well as the optimal level of statutory control. We argue that in Brazil this trade-off between credibility and control of the agencies is key to understanding the specific regulatory institutions that have been chosen. Comparative static results are derived to examine how changes in some key variables affect the design of the agencies, providing us with a set of hypotheses for comparing the design of five different agencies created to regulate industries with very different characteristics. Although these agencies were initially created under very similar designs, they are expected to evolve in ways that accord with our theory.

KEYWORDS: Regulation; credibility; regulatory agencies; asymmetric information. JEL Classification: L5; K2; D82.

\section{INTRODUCTION}

One of the major themes in regulation literature is the principal-agent relationship between politicians and agencies, and in particular the trade-off that arises between flexibility and control (Weingast 1984; McCubbins and Schwartz 1984; McCubbins, Noll and Weingast 1987, 1989; Spiller 1990; Laffont and Tirole 1993; Epstein and O'Halloran, 1999). When delegating regulatory tasks, politicians would like to give the agencies ample powers and discretion in order for them to be able to effectively accomplish their mission. However, due to the information asymmetries inherent in these relationships, politicians run the risk that this discretion might be used to pursue outcomes that could harm their interests. The literature shows that this problem exists and is pervasive, and then goes on to describe how the parties attempt to deal with it (positive theories) or suggest solutions to make the relationship work in the most efficient manner in the light of the informational problems.

Given this hazard for politicians, it may seem surprising that they are willing to delegate to independent regulatory agencies so often, since in principle the same tasks could be accomplished by other bureaucratic forms, such as ministries and secretariats, that are easier to control. Clearly there must be some advantages for politicians in using autonomous agencies instead. What is it that a regulatory agency can deliver which an executive agency cannot?

One possible reason for creating a regulatory agency is to achieve a different type of administrative flexibility than is possible through the already existing executive offices. An autonomous agency can be put under different civil service rules that will enable it to attract, pay and motivate a talented work force (BresserPereira 1998). A second reason involves granting power to regulators so they have an incentive to specialize and reduce the uncertainty involved in the outcomes of that given sector. Although the bureaucrats charged with regulating a sector also have the opportunity to specialize, they lack the added incentive of being able to influence policy even when this implies moving against the preference of the Executive or Congress. Just as Congressional committees have been argued to play an informational role (Gilligan and Krehbiel 1987; Krehbiel 1991; Epstein 1997), there may be similar benefits in setting up regulatory agencies. A third reason that may moti- 
vate a government to adopt regulatory agencies is as a way of blame shifting (Fiorina 1982). Because the reforms and changes which several sectors have been going through necessarily imply a redistribution of wealth amongst different groups, the government may wish to distance itself from this process to avoid being blamed. ${ }^{1}$

A fourth reason for setting up regulatory agencies independent from the central government is to give a credible commitment that government will not interfere arbitrarily in the regulatory process in order to appropriate the rents from the regulated companies. Because occasions are bound to arise where the government will stand to gain from changes to the regulated sector, for example by reducing tariffs prior to an election or to stem inflation, investors require safeguards that these opportunities will not be acted upon. These safeguards can take the form of the institutional endowment of the country, such as an independent judiciary and a divided government (Levy and Spiller 1996; Spiller and Volgelsang 1997). They can also exist in the way the regulatory agency is designed. By appropriately designing the agency's framework, the government can reduce scope for government opportunism and thus reassure investors. This can be done by through the specific rules regarding the agency's budget, the process of nomination and substitution of regulators, requirements for making different types of decision, etc. If the design is to provide a credible commitment on the part of the government, it must actually provide binding constraints and therefore these cannot be simply superficial features, but rather must concern fundamental characteristics of the agencies. This implies that, in countries where credibility is an important concern for the government, we can explain much of the choice of regulatory institutions as a way of providing this commitment.

In this paper we argue that the most important motive for the creation of regulatory agencies in Brazil, as well as the main determinant for the specific regulatory design chosen in each sector, was the issue of credibility. Brazil has a history replete with examples of government opportunism; debt payment moratoriums, confiscation of savings, use of utility tariffs to control inflation, several price freezes, manipulation of economic variables, reneging of contracts, disrespect of intellectual property rights, arbitrary rule changes, etc. This is illustrated by the fact that despite Brazil's larger and more stable economy and politics, it has a lower credit risk rating than Colombia. ${ }^{2}$

Given this history, it is clear that the issue of credibility was a major concern of the Brazilian government as it launched one of the largest privatization programs in

\footnotetext{
${ }^{1}$ For example, in Brazil it has been suggested by a noted economist that regulatory agencies were created partially to act as scapegoats: "Their existence allows the government to avoid at least part of the blame when the process of privatization generates problems for consumers." Cysne, R.P., 1998, "Regulação e Competição,” O Globo, July 14, 1998, p. 7.

${ }^{2}$ Moody's Investor Service, July 30, 2000, http://www.moodys.com/repldata/ratings/ratsov.htm. Brazil's rating for long-term bonds is $\mathrm{B} 2$ whereas Colombia's is Ba2. According to the rating definitions: "Bonds which are rated B generally lack characteristics of the desirable investment. Assurance of interest and principal payments or of maintenance of other terms of the contract over any long period of time may be small.
} 
the world in the mid 1990s. From 1997 to 2000 six regulatory agencies were created (telecommunications, electricity, petroleum, health plans, food \& drugs and water), and plans exist for the creation of several more (transport, civil aviation and sanitation). Before the agencies were created regulation of the sectors was not absent. Specific ministries, or offices within the ministries, regulated the public and private companies in each sector. The change to autonomous agencies has not been innocuous; it represents a very dramatic change in the organization of government, with a significant shift in the locus of power. We argue that the main motivation behind this change was the government's need to tie its own hands, providing a commitment to reassure investors, and thus guarantee a successful privatization program.

In the next section we develop a model of the process of regulatory design that captures the fundamental trade-off between control and credibility. When faced with the problem of how to set up the agency's structure and process, and who to appoint as regulators, the government will wish to set things up so it can keep close control of policy outcomes. However, this control embedded in the agency's design is not free; it generates a credibility cost that the government must also consider. This cost arises from investors' reaction to the perceived risk of government expropriation of their assets, as described by Savedoff and Spiller (1999, p. 8):

The direct costs of expropriation - either directly or through administrative measures - include reduced investment by other operators in the infrastructure and utilities sectors who will, as a result, consider further commitments as increasingly risky. The institutional costs of such expropriations are to undermine the effectiveness of basic rules and norms of governance by disregarding judicial findings or evading proper, or traditional, administrative procedures. ${ }^{3}$

The model in this paper determines the optimal amount of control the government chooses to exert through the agency's design. It also determines the preference of the regulator who will be appointed to head the agency. Together, these two variables endogenously determine the final policy outcome. The model is then used to derive comparative static results that illustrate how these choices are affected by changes in credibility costs, presidential preference intensity and agency preference intensity. These results are used in section 3 to guide the analysis of the five regulatory agencies created in Brazil so far.

Interestingly, the choice of institutional design for each of these different agencies has been very similar, despite the fact that each sector has very important distinctions, in particular regarding the type of company being regulated, the type of product or service, the interest groups involved, the level of competition, the level of expertise required, the rate of technological change and the potential po-

\footnotetext{
${ }^{3}$ Savedoff, W.D. and P.T. Spiller, 1999, Spilled Water, Washington D.C., Inter-American Development Bank.
} 
litical costs and benefits. We suggest that this isomorphism of agencies is due to lack of experience and the short time that they have existed for, and that this situation is not well-balanced. Our expectation is that the forces highlighted in our model will gradually lead the agencies to be redesigned and to their growth in the directions predicted by the theory. We provide evidence that this has already been occurring and suggest where we expect changes to occur in the future.

One can also attribute these similarities in the agencies' institutional design to the dominance of the Brazilian executive in the decision-making process in Congress. This dominance has posited legislators against executive initiatives regarding regulatory agencies. Thus, with no other alternative, Congress has generally supported presidential preferences in relation to regulatory design (Pereira, Costa, Goovanella, 2001).

\section{A MODEL OF REGULATORY DESIGN WITH CREDIBILITY COSTS}

In this section we present a simple model that captures some of the main issues involved in the design process of regulatory agencies and institutions. As discussed in the previous section, the fundamental problem faced by the Brazilian government in the creation of a new regulatory system during the second half of the 1990s was the trade-off between credibility and control. On one hand, it was necessary to create an environment where providers of public utility services felt assured that they would not be administratively expropriated by the government, thus giving the firms positive incentives for investment and production. On the other hand, the government was aware that this act of delegation created the potential for the agencies to pursue their interests at the expense of its own. The trade-off lies in the fact that any attempt by the government to structure the regulatory system so as to restrict the agencies' ability to deviate from its interest, has the effect of reducing the system's level of credibility, thus leading to loss of investor confidence and consequently poorer economic performance. Whereas this trade-off is present to some degree in any country where regulation is practiced, we argue that in the case of Brazil it is one of the main reasons behind the choices of regulatory design. The model in this section seeks to illustrate how this trade-off affects these choices. This will then allow us to do comparative statistics to see how changes in some key variables affect the design of the agencies, providing us with a set of hypotheses that can be tested, in the next section, by comparing the designs of different agencies created to regulate industries with very different characteristics.

The model takes place is the context of a country with no tradition with regulation through "independent" agencies. The need for regulation has arisen because the country is in the process of privatizing and reforming many of its public utility sectors. ${ }^{4}$ The driving force behind the privatizations, reforms and establishment of a regula-

\footnotetext{
${ }^{4}$ In Brazil the regulatory system was established simultaneously with the process of privatization, despite the obvious advantages that it should precede.
} 
tory system is the Executive. Although the great majority of the literature on regulation understands the legislative body as the principal who delegates powers to regulatory agencies, in Brazil it is the Executive which has taken this initiative. This does not mean that the Brazilian Congress does not care about regulation. However, due to its constitutional and procedural powers the Brazilian Executive has largely dominated the process of creation of new legislation..$^{5}$ In addition, the decision-making process inside the Brazilian Congress is extremely centralized favoring the Executive and its party leaders who have power to distribute political and financial benefits to politicians. The Executive has made large use of this distribution in order to gain legislative support according to its preferences (Pereira 2000; Pereira \& Mueller 2001). This has conferred to the Executive significant power in setting the legislative agenda. To get an idea of the Executive's dominance, especially related to regulation, all five regulatory agencies that have been created so far by the Brazilian Congress have been done so through bills initiated by the Executive which were approved by unanimity in both houses. Therefore, our model assumes that during the period under investigation the Congress' median preference was similar to that of the Executive.

When confronted with the need to create a regulatory agency for a given sector, the president has clear preferences as to the outcomes he would like to see resulting from the agency's actions. These preferences are taken as given and are assumed to arise from some form of net political support maximization by the president, which takes into account how the different outcomes affect the various groups in society and how these groups respond in terms of support and opposition (Stigler, 1971; Peltzman, 1976; Denzau and Munger, 1986). We assume additionally that the issues involved can be expressed in a one-dimensional space, so that each actors' preferences can be represented as a point on line, with utility declining the further the outcome from each member's preferred point. ${ }^{6}$

In order to establish a regulatory agency the president needs to determine three points; (i) the agency's structure and process; (ii) who to choose to head the agency; and (iii) the initial policy point. The agency's structure and process is essentially the design of the agency. The structure specifies its internal hierarchy and the process establishes what procedures have to be followed in order to take any action, for example to change the firm's tariff. Together the structure and process establish the regulatory institutions that determine how the agency will function, what are its restrictions and its prerogatives, the sequence of proposal and veto gates, which external parties can participate and in what manner, etc. ${ }^{7}$ Following the main in-

\footnotetext{
${ }^{5}$ Pereira, Carlos and Mueller, Bernardo (2000), “Uma Teoria da preponderância do Executivo: O Sistema de Comissões no Legislativo Brasileiro". Revista Brasileira de Ciências Sociais, 15(43): 45-67.

${ }^{6}$ The single dimension can be, for example, the tariff allowed by the regulator to the firm. The firm's preferred point is the monopoly price and the preferred point of the president will depend on the outcome of the interest group/electoral pressures. If the president obtains most of his support from consumers his preferred point will be closer to the competitive price, and the greater the political influence of the firm, the closer the president's preferred point to that of the firm.

${ }^{7}$ Bawn (1997) has argued that politicians can exert control over agencies ewither through statutory
} 
sight of the rational choice literature on the organization of administrative agencies [McCubbins, Noll and Weingast (1987, 1989), Macey (1992), Calvert, McCubbins and Weingast (1989), Bawn (1997)], we recognize that the president will set the agency's structure and process strategically to keep it from acting against his interest. This need arises because there is a principal-agent problem between the president and the agency, so that the president cannot costlessly monitor all the agency's action, nor force it to behave through threats of ex-post punishment. By carefully designing structure and process the president reduces the agency's flexibility in ways that allows him to notice any deviation before it occurs, often with the help of specific groups empowered by the agency's procedural rules [McCubbins and Schwartz (1984), Lupia and McCubbins (1994)]. This allows him to intervene and forestall the deviant behavior. There is therefore an important trade-off between flexibility and the control of the agency, to which we add in this paper, the credibility effects of the specific regulatory design chosen by the president.

The second choice that must be made by the president is who will be the head of the agency. As we will see in the next section, a commission composed of a small number of commissioners, one of whom serves as its president, heads all regulatory agencies in Brazil. In the model we treat the agency as a unitary player with a given preference, thus implicitly assuming a median voter result. We assume also that the president has a large pool of individuals from whom to pick, so that he has the possibility of choosing an agency with any preference in a reasonable range. If the president had no restrictions, one would expect him to choose a regulator with preferences identical to his own, thus eliminating the threat of a distributive loss due to agency deviation. However, given the importance of the names chosen to head the agency, the president must consider the credibility effect of his choice. Once this effect is taken into account it is possible for the president to choose a regulator with preferences that differ from his own, as will be shown in the model below.

The third choice that must be made when establishing a regulatory agency is the content of the initial policy that the president wants the regulator to follow. In Brazil, where the regulatory agencies were created at the time of privatization, and where the transferal of the firms to the private sector has been done through concession contracts, the initial policy points are expressed to a great extent in the contracts themselves. For example, the initial tariffs and tariff revision mechanisms are detailed in the contract, thus setting the initial status quo with regard to that area. The same is true for several other dimensions, such as the quality targets the firms must achieve and the extent of universalism of service. Other issues may not be in the contracts but in the agencies mandate or in the laws that create the agency. The point is that when creating an agency the initial policy must be determined. This choice however, is not independent of the other two choices mentioned

control or through direct oversight. Furthermore she argued that there is substitutability between these forms of controls. Although we focus in this paper on the statutory control provisions that make up the agency's structure and process, the president's choice of the level of oversight could be treated analogously. 
above. Because of the asymmetric information between the president and the agen$\mathrm{cy}$, and because both do not necessarily have the same preferences, the president is not free to choose any policy point and to expect the agency to implement it faithfully. The principal-agent nature of the relationship between them restricts the policy points that the president can choose. In fact, as will be shown in the model below, how close to his preferred point the president can set policy will depend crucially on where he sets the agency's preferred point and on the specific design he chooses for the agency. That is, once these two choices have been made, the policy point arises endogenously from the model.

Although the two choices are made simultaneously we start by modeling them separately, as if the president first chooses the agency and then sets the structure and process. This is done so as to allow us to analyze each choice individually. Subsequently we model the more realistic scenario where both choices are made simultaneously. In order to analyze the choice of agency preference by the president separately, we assume that he derives utility from the location of the agency. This is not very realistic since the president derives utility from policy outcomes and not from agency preference, but it can be thought of as if the president were thinking of the agency preference as an indicator of the policies that the agency will pursue. When we turn to analyzing the two choices simultaneously, we will drop this assumption and allow the president to receive utility only from policy outcomes.

In figure 1 panel A we show the president's preferred point $P$ along a single dimension. As noted above, this point is taken as exogenous. The president's utility is $U^{P}=-\alpha|A-P|$, where a is a preference intensity parameter that is equivalent to the absolute value of the slope of the president's utility curve, and $A$ is the preferred point of the chosen agency. The further the president sets $A$ from $P$, the lower will be his utility. Note also that the more the president is concerned about how far the agency's preferences are from his, the steeper will be his utility curve and the higher $\alpha$ will be. ${ }^{8}$

Point $T$ represents the point where the agency would be set if that choice were made based only on efficiency criteria and not on political or strategic concerns. That is, it is the point that a social welfare maximizer would pick, and as such, it is the point that, if chosen by the president, would yield the highest level of confidence from the market. As in the case depicted in figure 1, the president's preferred point $P$ will not necessarily coincide with $T$, so he may wish to deviate from this "efficient" point by pulling $A$ closer to $P$ and further from $T$. This is not cost free, however. All the participants in the market perceive the deviation of the president's choice from the efficient point and adjust their expectations and their behavior accordingly. In particular, both current and potential investors become wary and perceive a greater risk in making further investments, especially those involving specific and sunk assets. This reaction by investors generates a cost for the government as it will suffer increased risk discounts in future privatizations and other

\footnotetext{
${ }^{8}$ The mathematical description of Figure 1 and Figure 2 as well as the comparative static are available upon request.
} 
investments by the private sector. More generally, this behavior by the president makes it harder to signal commitment in many other areas of action, thus leading to a costly loss of credibility. The magnitude of this cost depends not only on the size of the deviation from $T$, but also on the acquired reputation of the government. For a country like Brazil, with a history of governmental expropriation from citizens and investors, this commitment cost can be quite high.

The existence of a commitment cost does not mean that the president will necessarily place the agency at $T$. His choice will be governed by the trade-off between the utility gained by pulling $A$ closer to $P$, and the credibility loss from doing so.

Let the commitment cost be $C=\theta(A)$ where ${ }_{A}>0,{ }_{A A}{ }_{A}>0 .{ }^{9}$ It is reasonable to assume that as $A$ deviates from $T$, the commitment cost grows at increasing rates, that is, the more that the president appears to be set on controlling the agency, investors' reactions increase more than proportionally. In panel B of figure 1 we show the resulting level of utility for the president from placing the agency at $A_{1}$ instead of at $T$. Each unit closer to $P$ has two effects on the president's utility. The first is a marginal benefit equal to the increased utility from having an agency more compatible with his own interests. This marginal benefit is constant, given the straight utility curves, and equal to a the absolute value of the slope of the president's utility. ${ }^{10}$ The second effect is a loss of credibility from choosing an agency with preferences different from the "efficient" point. This loss is a marginal cost whose magnitude depends on how far $A$ is set from $T$. For an agency at $A_{1}$ the marginal cost will be $\theta_{A 1}$, where the subscript means a derivative. In figure 1 panel $\mathrm{B}$ the move from $T$ to $A_{1}$ yielded a net increase in utility, since the marginal loss in credibility was smaller than the distributive gain for the president, that is, $\alpha>\theta_{A 1}$.

As the agency is pulled closer to $P$, the marginal benefit remains the same and the marginal cost increase. Points $A_{2}$ and $A_{3}$ and their associated utilities are represented in panel B. It can be seen that as the chosen agency point distances itself from $T$, the credibility cost grows disproportionately. In panel $C$ the full locus of relevant utility outcomes are shown. Note that at point $P$ the president will have the agency at his preferred point but will suffer a credibility cost of $\theta(P)$ that more than outweighs this gain. The utility maximizing point occurs at $A_{2}$ where marginal benefit equals marginal cost, $\alpha=\theta_{A 2}$. Figure 1 shows an example where an interior solution is reached. It is possible, however, that the optimal point will be at either $P$ or $T$. The former would occur if the credibility cost were very low, relative to the slope of $U^{P}(A)$, and the latter if the credibility cost were very high. The following proposition summarizes the optimal choice of agency preference by the president:

\footnotetext{
${ }^{9}$ The credibility cost is a function of the absolute value of the distance from $T$ to $A, C=q(|T-A|)$. However, to simplify notation we place as argument in the cost function just the point where the agency is placed, since $T$ is given.

${ }^{10}$ Figure 1 and the discussion in the text portrays a specific example with $T>P$. The generalization to other configurations of preferences is straightforward.
} 
Proposition 1 - For all $A \in[P, T]$

if there exists $A^{*}$ such that $-\alpha=\theta_{A^{*}}$ then the optimal point is $A^{*}$;

if for every $A,-\alpha<\theta_{A^{\prime}}$ then the optimal point is $A^{*}=T$;

if for every $A,-\alpha>\theta_{A^{\prime}}$ then the optimal point is $A^{*}=P$.

Figure 1 Choice of Agency Preference

I

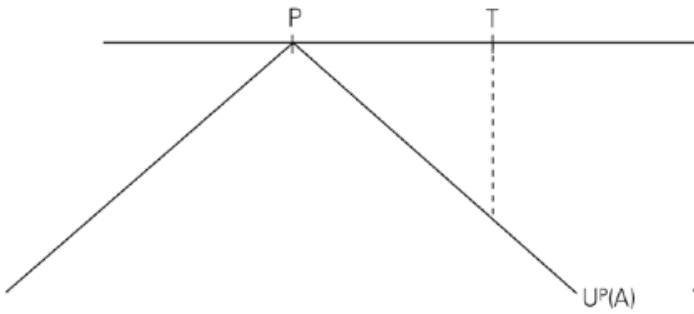

Abs. value of slope of $U^{P}(A)=\alpha$

II

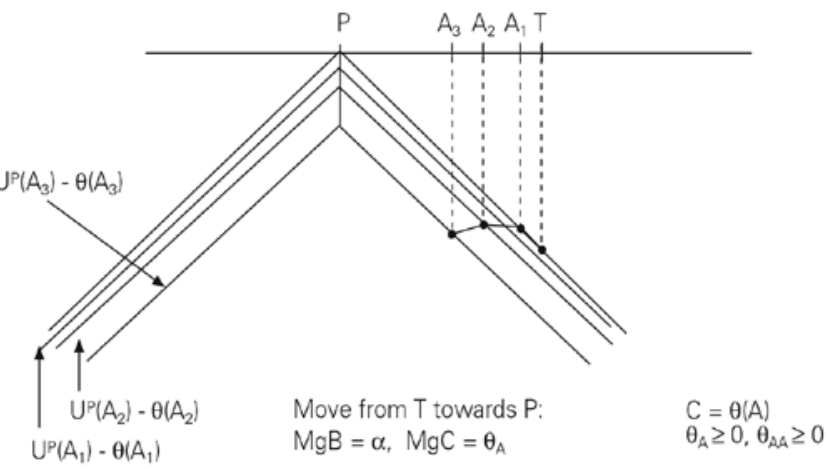

III

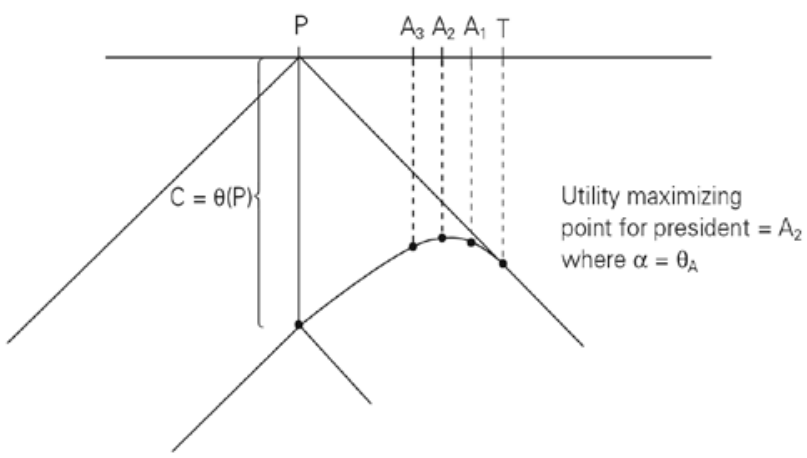


Having shown what determines the president's choice of agency preference we now take $A$ as given and turn to the question of agency design. More specifically we want to analyze what determines the level of statutory control that the president chooses to embed in the agency's structure and process. According to McCubbins, Noll and Weingast (1989) "the tools available to political actors for controlling administrative outcomes through process, rather than substantive guidance in legislation, are the procedural details, the relationship of the staff resources of an agency to its domain of authority, the amount of subsidy available to finance participation of underrepresented interests, and resources devoted to participation by one agency in the process of another." Although these are very different instruments that work along different dimensions and may be both substitutes and complements, we simplify by assuming that the level of control built into an agency's structure and process can be treated as a single variable, $D$. The higher the level of $D$ chosen by the president, the more cumbersome will be the procedures the agency will have to follow to make any policy change. We interpret $D$ as creating costs for the agency to change the status quo policy. ${ }^{11}$ Thus, when creating the agency, the president can establish the status quo and impose a level of $D$ such that the agency will see no difference between changing the policy to its preferred point $A$ or leaving the policy at the status quo. This is shown in figure 2 panel A, where, for a given value of $A$, the president chooses a level of $D^{x}$ that will support policy $x$. If the agency chooses to move the policy from $x$ to $A$ its utility will be $U^{A}(A)-D^{x}$ rather than to $U^{A}(x)$, which are equal. Given this level of $D$, if $x$ were set any closer to $P$, the agency would be better off by moving the policy to $A$ even though it would incur the utility loss due to $D$. If, on the other hand $x$ were placed at any point closer to $A$, the agency would choose not to change the policy.

If establishing the level of political control $D$ were cost free for the president, then he could chose a level $D^{P}$ (see panel C) that would support his preferred policy $P$. However, as in the case of agency choice, we assume that indulging in this form of political control generates a credibility cost for the president. This cost function is $C^{*}=\Omega(D)$, where $\Omega_{D} \geq 0$ and $\Omega_{D D} \geq 0$. As before, an increase in the level of control by the president implies a disproportional increase in credibility cost. In panel B the utility outcome for the president is shown for the case where he imposes no controls over the agency and thus suffers no credibility loss (point I). If instead he chooses to impose a small level of control, $D^{x 1}$, he will be able to support policy $x_{1}$, which is slightly closer to $P$. Doing this increases his utility since the marginal benefit due to this move is higher than the marginal cost. It can be shown that the marginal benefit due to a one unit move toward $P$ is equal to a/g, where $\mathrm{a}$ is the absolute value of the president's utility curve and $\mathrm{g}$ is the absolute value of the agency's utility curve. The effect of the marginal benefit of imposing $D^{x 1}$ is to move the president's utility from point I to point II. However, the increased

\footnotetext{
${ }^{11}$ See Spiller and Tiller (1997) for a similar treatment where decision costs must be borne by an appeals court if it overturns a decision by an agency.
} 
use of control leads to a credibility loss by the president of $\Omega\left(D^{x 1}\right)$, so that the marginal cost is equal to $\Omega_{D}$. In the example given in panel $C$ the marginal benefit outweighs the marginal cost, so the use $D^{x 1}$ rather than no control at all leads to a welfare gain, as can be seen by comparing the final outcome point III to the initial utility point $\mathrm{I}$.

In panel $\mathrm{C}$ the entire locus of possible utilities for the president is shown. In this example the optimal level of political control is $D^{x^{*}}$ which supports policy at point $x^{*}$. At any level of $D$ greater than this the credibility cost would outweigh the distributive benefits, and for any lower $D$ the president could do better by exerting more control. As before, the final outcome depends crucially on the form of the credibility cost function $C^{*}=\Omega(x)$. Although the example in figure 2 shows a case with an interior solution, for many plausible cost functions the final outcome would lead to policy at either $P$ or $A$. The optimal choice of political control $D$ built into the agency's structure and process is summarized in the following proposition: ${ }^{12}$

Proposition 2 - Assuming $A>P$ so $x^{*} \in[P, A]$

if there exists $x$ such that $\frac{\alpha}{\gamma}=\Omega_{D^{\prime}}$ then the optimal policy is $x^{*}=\frac{D^{*}}{\gamma}$;

if for every $x, \frac{\alpha}{\gamma}<\Omega_{D}$, then the optimal policy is $x^{*}=A$;

if for every $x, \frac{\alpha}{\gamma}>\Omega_{D}$, then the optimal policy is $x^{*}=P$.

In the preceding analysis we modeled the president's choice of agency preference and his choice of agency design separately. This was done to facilitate exposition and allow us to focus on each choice individually. In actual fact, however, both choices are made simultaneously. Furthermore, we now want to drop the assumption that the president's utility is determined by the agency preferred point, allowing it to be determined only by final policy outcomes. Now the credibility cost is simultaneously a function of both of these variables so rather than having $\theta(A)$ and $\Omega(D)$, the credibility cost is $\Phi(A, D)$, where ${ }_{A} \geq 0,{ }_{A A} \geq 0,{ }_{D} \geq 0,{ }_{D D} \geq 0$ and $\Phi A D \leq 0 .{ }^{13}$

It can be seen that the final choices in the joint problem are very similar to those of the individual cases. The two main differences are the joint cost function and the fact that now the choice of $A$ affects the president's utility only indirectly. In all other respects the analysis in figures 1 and 2 remain valid. The results are summarized below:

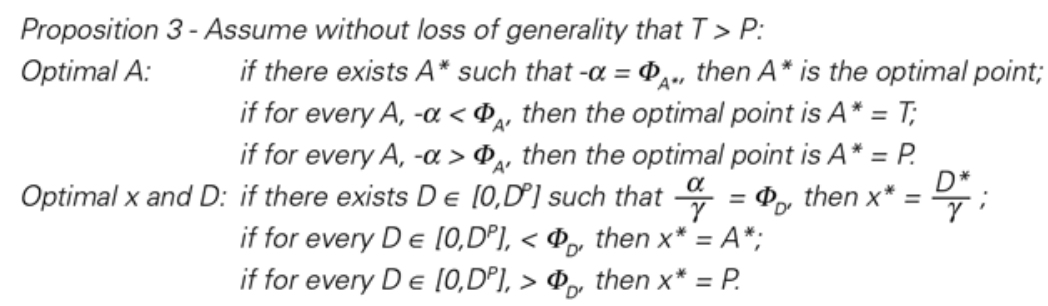

\footnotetext{
12 The results for the case where $A<P$ are analogous.

${ }^{13}$ These assumptions imply that $A$ and $D$ are complements in relation to the president's credibility cost. That is, the more the president indulges in one form of control the higher will be the cost of another unit of the other.
} 


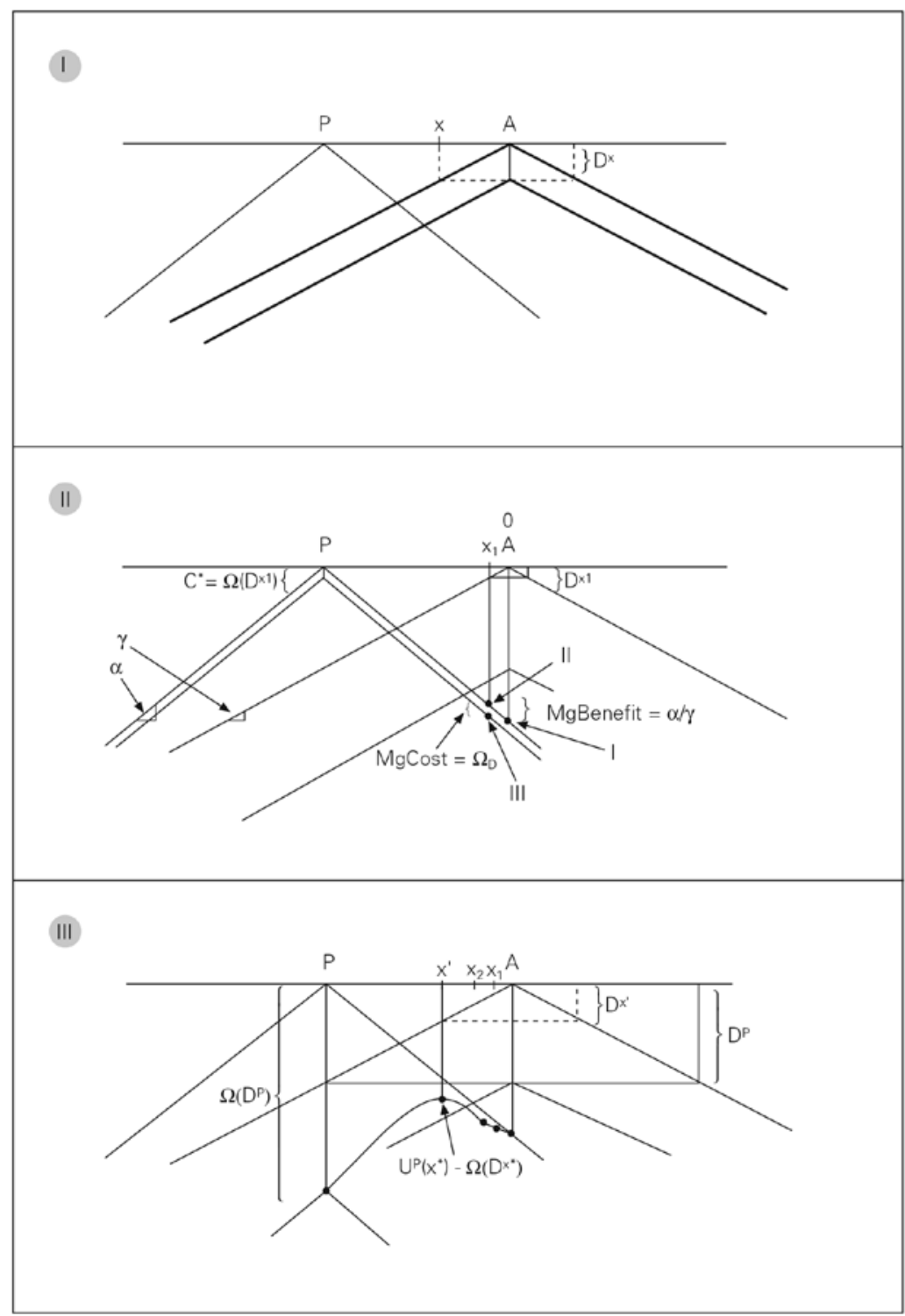

The results above capture the importance for the government to make a commitment that it will not intervene arbitrarily in the regulated markets. These results are in fact intuitive. When choosing whom to appoint to the agency the president wants to choose people with preferences similar to his own, but consideration must also be given to the effect this choice will have on the government's credibility. If the credibility cost is very low the president appoints his preferred regulators. If the credibility costs are very high the president, as a means to commit to not interfering, 
will appoint as regulators those people whom the market consider the most technically qualified and politically neutral. If, however, the credibility costs are of the same order of magnitude as the benefits to having more collegial regulators, then it is possible that the chosen regulators will be somewhere in between the market's and the president's preference. The same logic holds for the choice of statutory control. If credibility is not a concern, the president will make plentiful use of these controls so as to assure that the agency will produce results close to those desired by the president. If credibility is a concern, the president will commit by not writing these controls into the agency's design, and as a result outcomes will be close to the agency's preference. If credibility concerns are closely counterbalanced by distributive concerns, then the president will choose an intermediary level of control that will lead to policy outcomes in between the preferred outcomes of the agency and the president.

From the above discussion it is clear the design of regulatory institutions may be determined to a large extent by credibility restrictions and the need to provide commitment. In different countries credibility will impose differing levels of constraints on governments, so it is not surprising that regulatory institutions are fundamentally different worldwide. However, even in the same country different regulated markets can have very different characteristics regarding the cost of credibility, as well as the preferences of the president, the agency and the market. In the next section we will use the insights from the model above to compare the regulatory institutions in different regulated markets in Brazil. In order to guide this comparison we first provide comparative static results to establish the expected effects of changes in key parameters.

Result $1-$ Change in the president's preference intensity (parameter $\alpha$ ): $\frac{d D}{d a}>0 \quad$ The higher the value of $\alpha$ the more intensely the president feels about $d a$ the final policy outcome, that is, the steeper his utility curves. This results shows that ceteris paribus the stronger the president feels about outcomes in a given regulated market the more statutory control will be built into the agency's design.

$\frac{d A}{d \alpha} \geq$ or $\leq 0 \quad$ The effect of an increase in the president's preference on the optimal location of the agency is ambiguous and depends on two effects. The first is that a more sympathetic agency (lower $A$ ) reduces the amount of statutory control that will be necessary, thus reducing the marginal cost of control (through $\Phi_{\mathrm{DD}}$ ). On the other hand, a lower $A$ also increases the marginal cost of this control (through $\Phi_{\mathrm{DA}}$ ), that is, the more the president "cheats" when choosing the agency heads, the more weary the market will be of any control $D$. The actual change in $A$ can thus go either way.

Result 2 - Change in the agency's preference intensity (parameter $\gamma$ ):

$\frac{d D}{d \gamma}<0$ - The stronger the agency's preference concerning final policy outcomes, $d \gamma$ that is, the higher $\gamma$, or the steeper its utility curves, the less 
statutory control will be chosen by the president. This happens because the stronger the agency's preference the smaller the marginal benefit for the president from increasing control, since a given $D$ will yield a smaller shift of the outcome towards the president's preferred point.

$\frac{d A}{d \gamma}>0 \quad$ The stronger the agency's preference the closer the president will put $d \gamma$ the agency to the market-preferred point $T$. This happens because with a higher $\gamma$ the effect of $A$ on the marginal credibility cost from setting $D$ increases, so in equilibrium $A$ is raised to be closer to $T$.

Result 3 - Change in credibility cost parameter $\pi$ :

Let $\pi$ be a parameter of the cost function $\Phi(A, D, \pi)$ that increases the credibility cost for any given level of $A$ and $D$.

$\frac{d D}{d \pi}<0$ - The higher the concerns with credibility issues, the lower the level $d \pi$ of statutory control that will be used by the president, ceteris $p a-$ ribus.

$\frac{d A}{d \pi} \leq$ or $\geq 0-$ An increase in credibility concern has an ambiguous effect on the optimal location of the agency. On the one hand the president reacts to a heightened investor fears by choosing an agency closer to his own preference, that is a lower $A$, since this will reduce the costs of him using controls $D$. On the other hand the higher $\pi$ means that the effect of $A$ on the marginal cost of using $D$ is higher, which leads to a higher $A$. Which effect is stronger is in the end is an empirical issue.

\section{REGULATORY DESIGN IN BRAZIL}

The previous section presented some clear hypotheses concerning the regulatory process in environments where credibility is an important concern. Because this is the case in Brazil, we now examine the regulatory institutions that have developed in this country in the light of those hypotheses. We have argued above that when Brazil started its privatization program in the 1990s one of its greatest problems was to signal to the markets that it would not act opportunistically once it had passed the ownership of the state companies over to private hands. Given the government's reputation, doing so required making strong, credible commitments. One of the main ways through which this was done, we argued, was through the creation of autonomous regulatory agencies. The first three agencies were created in sectors that composed the core of the government's privatization program; electricity, telecommunications and petroleum (see tables 1, 2 and 3 for details). These sectors are still currently in the process of being reformed and privatized, a process that will extend into the future. 
The scope of the change being undertaken as well as the values involved is monumental. Clearly there were good reasons for the government to try to signal commitment. More recently two new regulatory agencies have been established; health insurance plans, and food \& drugs (see tables 1, 2 and 3). These sectors are distinct in many ways from the previous three, as are the sectors in which new agencies are currently being planned; civil aviation, transport and sanitation.

Brazil therefore presents an opportunity to test the hypotheses above; credibility has been a key factor and several regulatory agencies have been created at approximately the same time, each related to a different sector with different characteristics and particularities. Table 1 gives some of these characteristics. To underscore the variability of the sectors being regulated, consider how different is the task of each agency. ANEEL and ANATEL regulate recently reformed and privatized markets. While the first of these remains partly monopolized, in distribution and generation, the other is becoming reasonably competitive. ANP on the other hand faces the task of regulating Petrobras, the huge and powerful state petroleum company, which is not yet considered for privatization. As for ANS and ANVISA, they regulate markets that are competitive and that have not been involved in privatization. Whereas electricity, telecommunications and petroleum still have much to be privatized in the next several years, health is already a completely private market, and food \& drugs a mostly private one. Electricity and especially telecommunications are undergoing accelerated and unpredictable technological change, whereas health plans and food \&and drugs face fairly stable technologies. Although all of the products of these regulated sectors are an important part of the average consumers' basket, some are seen as having a more social role, and thus present a bigger temptation for politicians to try to manipulate. In the same manner some of the products have a higher effect on inflation, and as such are more likely to be the object of government interference.

The above list of differences between the five regulated sectors does not purport to be complete. Its purpose is simply to stress the variability between the sectors. If the model presented above is a good representation of the regulatory process, one would expect that the agencies created for each of these sectors would vary, in terms of design and regulator preferences, in accordance to its results. That is, we should be able to classify each sector as having a higher or lower credibility cost $(\pi)$, presidential preference intensity $(\alpha)$ and agency preference intensity $(\gamma)$, and examine to see if each agencies' design $(D)$ and preference location $(A)$ correspond to these as predicted by the theory. For example, for the model to be correct we should expect to find that in those sectors where credibility is more of an issue, due to ongoing privatizations, the agencies' designs should exhibit less presidential control.

However, when we compare the formal design of the five agencies, we find that they are remarkably similar. Table 3 shows that the agencies' designs present only very slight variations regarding their appointment process, board composition rules, budgetary sources and other details of their structure and process. Even the forms of oversight built into each agencies' design, presented in table 2, vary very little, 
whereas our theory would expect to see great differences according to the level of credibility cost in each sector. The small differences that do exist are not systematic and are difficult to interpret. For example, ANEEL, ANVISA and ANS have a governance contract, that provides an instance and a forum where the agency must periodically account for its actions, while ANATEL and ANP do not have this form of supervision. Nevertheless there are other forms of oversight in these two latter agencies that may well have the same effect, like the advisory council in ANATEL's structure. We therefore avoid reading much into these small details as this risks leading to premature conclusions.

Although this isomorphism of the five agencies indicates that our model is not a good representation of the regulatory process in Brazil, we suggest a different interpretation. Brazil is still in the beginning of its regulatory experience. The five agencies were created very recently and are a new organizational form for the country. We suggest that the similarity in the agencies' structure is a result of this lack of experience and the Executive's rush to implement changes in each different sector. In this situation the government simply used the same mold to create each agency. ${ }^{14}$ That is, we believe that the process of agency design is not yet balanced and that, given that the sectors are so different, there will be forces that will push for changes as time goes on. We thus expect that in the next years we will observe the differentiated evolution of the agencies, including those still to be created. In some, the government will tighten controls, others will be left alone and others still may even be extinguished. If these changes do in fact take place we will be in the position to test our model, since it makes clear predictions of the direction each change will take.

Given the early stage of the process we are unable to present systematic evidence. However an examination of some of the details of the agencies' early design does suggest that the forces we identified are at work. Regarding two regulatory agencies that were created to regulate markets that have always been private, ANS and ANVISA (that is low credibility costs sectors), the executive has systematically initiated new legislation through Provisional Decrees. This suggests a higher level of executive interference and as a consequence a lower level of agency autonomy. On the other hand, the other three agencies, ANEEL, ANATEL, and ANP, have suffered less executive interference through Provisional Decrees. Regarding ANP and ANEEL, Pinto (2001) states that the governmental body responsible for establishing energy policy guidelines, CNPE (National Council for Energy Policy), has

\footnotetext{
${ }^{14}$ Another reason why the agencies' structures have turned out to be similar, suggested by an anonymous source, may be the influence of the bureaucracy in the process of creating each agency. The bureaucracy at the Ministry of Communications was instrumental in the conception of ANATEL, the first agency to be created. The bureaucrats that participated in the subsequent agencies were similarly influential. Admittedly there is a principal agent problem between the Executive and the bureaucracies, eg ministries, which affects how the agencies got structured. In this paper however we ignore that possibility treating the Executive and the bureaucracy as united, and concentrating instead on the principal-agent problem between the Executive and the agency.
} 
not been defining the rules for the sector, as it was created to do. As a consequence the agencies have been the actual policy-makers in their respective sectors, establishing a set of new regulations/rules (portarias) to complement the institutional regulatory framework, giving them considerable discretionary power.

There are important institutional distinctions amongst the agencies that support our predictions. While ANEEL and ANATEL have the power to establish new tariff and price readjustments, ANP does not. It is the Ministry of Finance that controls the process of establishing new prices and tariffs in the petroleum sector. At the upstream level ANP basically regulates a single state-owned enterprise, Petrobras. Because the oil industry is not characterized as a natural monopoly the credibility cost the government faces for not allowing the agency to define tariffs is small. ${ }^{15}$ However, as ANEEL and ANATEL regulate competitive and recently privatized markets, which require clear safeguards for current and future investments, the government has opted to not interfer in the price and tariffs choices, signaling to the market that the agencies are in control of those decisions. This institutional choice certainly suggests that the credibility cost in those two areas is higher than that in the oil sector.

The pattern of the executive's appointments to the boards of the different regulatory agencies also fit with the relative need for credibility in each sector. Although there have been too few appointments thus far for us to test this more rigorously, those that have taken place provide some important clues. Roughly speaking, the board of ANEEL was composed by and large of members with an academic-technobureaucratic profile, originating mostly from ANEEL's predecessor DNAEE (National Department of Water and Electric Energy) and the previous public electricity companies. Of course, those choices were also politically motivated, as is the case in every appointment process. This sector has been under influence of the PFL, one of the political parties in the governing coalition, which has been responsible for the appointment of the Ministry of Energy since the beginning of the government. This influence extended to ANEEL where the leader of the PFL, Antônio Carlos Magalhães, nominated the majority of its directors.

However, it was in ANP that the political influence was most notable. ANP was not created to regulate a privatized sector and therefore a lower credibility cost was associated with its reduced level of autonomy. This agency was created through a political agreement between the two main political parties which give support to the government, PSDB and PFL. The agreement, widely reported in the media ${ }^{16}$, granted the PSDB the right to appoint three directors, including its president, David

\footnotetext{
${ }^{15}$ In fact, the pricing decisions in the oil sector are even more complex in Brazil. They depend also on the so-called "conta petróleo" and the PPE - Parcela de Preço Específica, which have important effects on the country's balance of payments. This is one of the possible reasons why the government has not decided to delegate the price and tariff decision to ANP.

${ }^{16}$ Newspaper O GLOBO, 11/01/1998, page 5 and Folha de São Paulo, 19/01/1998, p. 7.
} 
Zylbersztajn, who is an ex-son-in-law of President Cardoso, and the PFL the right to appoint the other two directors.

It can be assumed that ANATEL is the most autonomous regulatory agency. It was the brainchild of the Minister of Communication, Sérgio Motta, who attempted to protect it from political interference, including that from other branches of the Executive. He hired an international consultancy group to design the structure of the agency, which served as a model for the subsequent agencies. Concerning the composition of the board, he personally chose directors with clear technical and academic profiles. Moreover, the great majority of the ANATEL's board, including its president, Renato Guerreiro, enjoyed the deep trust of Minister Motta since they belonged to his personal cabinet in the Ministry of Communications.

The other two regulatory agencies, ANS and ANVISA, also had a personal stamp, this time of the Health minister José Serra. According to Bresser-Pereira ${ }^{17}$, former Minister of Administrative Reform, these two agencies were not originally designed to be independent regulatory agencies (which for him are responsible for state policies) but 'executive agencies' (responsible for government policies) with slightly less autonomy than a regulatory agency. However, when Minister Serra realized that a status of 'regulatory' instead of 'executive' agency would provide more access to resources and power, he advocated them to be made regulatory. The influence of the Health Ministry in these agencies is clear. As president of ANS, for instance, was selected a person of strict confidence of the Minister, who did not participate in the process of the agency's creation. The other directors came from the field of public health, social medicine and consumers' movements. As for ANVISA, it can be considered an extension of the former Department of food \& drugs of the Ministry of Health where a majority of its directors originated. Serra's appointees compose both agencies' boards and he has made no effort to conceal his control.

Further insights into the effect of credibility on the relationship between the executive and the regulatory agencies can be gained from the crisis of electricity supply that began in early 2001. Rather than allowing ANEEL to be in charge of setting up and administering the measures to deal with the problem, the government created, through provisionary decree $\left(\mathrm{n}^{\circ} 2.198-3,29\right.$ June 2001), a special committee whose president was the General Secretary of President Cardoso. ANEEL had a representative in the committee but he only played a marginal role. That is, the agency in charge of the electricity sector was seriously bypassed in this episode. The government blamed ANEEL for being responsible for the crisis and its president was publicly exposed as incompetent, unable to foresee the problem or to offer a solution. ${ }^{18}$

By intervening the government risked incurring future credibility costs. It should be remembered however, that in a situation of crisis and uncertainty, with the country facing the threat of power failures and blackouts, the market required a clear explanation about what measures were being taken and who was in charge.

\footnotetext{
${ }^{17}$ Personal communication.

${ }^{18}$ Newspaper Jornal do Comércio, 17 May 2001.
} 
In this case it is possible that the credibility cost would have been higher if the government had decided not to intervene. This may have been the rationale behind the government's choices. By creating the committee it was in effect pulling the agency to its preferred point in the model of the previous section. By doing this it incurred the associated credibility costs, but avoided the costs that would arise if the crisis were not properly dealt with. This strategy will take its toll in the future since the energy sector still requires substantial investments over the coming years, including privatization, all of which are affected by credibility issues. Nevertheless, the presence of the government can also signal that public investments in the sector will once again be undertaken, accompanied by better conditions and assurances for private investors. Whatever the result of the energy crisis, the issue of credibility will continue. The government will have to convince the market that this intervention was necessary and that it took place in atypical circumstances. One step necessary to do this will certainly be re-establishing ANEEL's autonomy as an independent regulatory agency. Otherwise, the government's entire effort to create a regulatory state will soon be under threat.

\section{CONCLUSION}

In this paper we presented a framework for understanding the process of regulatory design in countries where credibility is an important concern. When delegating tasks to an agency, the government will naturally be wary that the agency will use the principle agent slack to move outcomes towards its own preferences. The government will therefore try to build safeguards against this hazard into the agency's structure and process. Also, the government will want to choose regulators with preferences close to its own. But doing so may have an important effect on the signals investors receive concerning the government's propensity to indulge in opportunistic behavior if an occasion arises when this is in its interest. This means that the choice of design and the choice of regulators carry with them a credibility cost that the government must balance with the distributive gains of having more control. The model predicts when we might expect the government to have more or less control.

Brazil presents an excellent case study for testing these predictions. It is a country where credibility is a major issue and which is also undergoing important large-scale reforms and privatization in several diverse sectors. Unfortunately the process is still in an early stage and the agencies created have almost identical structures. Rather than taking this as evidence which contradicts our model we suggest postponing this conclusion until a time when the forces described in the model have had a chance to take effect.

However, recent evidence presented in this paper strongly suggests that this is in fact what has been already taking place. Therefore, based on this evidence, which corroborates our model hypotheses, it can be stated that further differences in the 
institutional design of the agencies will emerge. The same is expected concerning the level of interference of the Executive in agencies autonomy.

\section{REFERENCES}

BAWN, K., (1997). "Choosing Strategies to Control the Bureaucracy: Statutory Constraints, Oversight, and the Committee System.” Journal of Law, Economics, and Organization 13(1): 101-126.

BRESSER-PEREIRA, Luiz Carlos (1998). Reforma do Estado para a Cidadania: A Reforma Gerencial Brasileira na Perspectiva Internacional. São Paulo: Editora 34/ENAP.

CALVERT, R. L., M. D. MCCUBBINS, et al. (1989). "A Theory of Political Control and Agency Discretion.” American Journal of Political Science 33(3): 588-611.

DENZAU, A. T. and M. C. MUNGER (1986). "Legislators and Interest Groups: How Unorganized Interests get Represented.” American Political Science Review 80(1): 89-106.

EPSTEIN, D. (1997). “An Informational Rationale for Committee Gatekeeping Power.” Public Choice 91: 3-4.

EPSTEIN, David and O'HALLORAN, Sharyn (1999). Delegating Powers: A Transaction Cost Politics Approach to Policy Making under Separate Powers. Cambridge: Cambridge University Press.

GILLIGAN, T. and K. KREHBIEL (1987). "Collective Decision-making and Standing Committees: an Informational Rationale for Restrictive Amendment Procedures.” Journal of Law, Economics, and Organization 3: 287-335.

KREHBIEL, K. (1991). Information and Legislative Organization Ann Arbor: University of Michigan Press.

LAFFONT, J. J. and J. TIROLE (1993). A Theory of Incentives in Procurement and Regulation Cambridge: Massachusetts Institute of Technology Press.

LEVY, B. and P. T. SPILLER (1996). Regulations, Institutions, and Commitment: Comparative Studies of Telecommunications. Cambridge: Cambridge University Press.

LUPIA, A. and M. D. MCCUBBINS (1994). "Learning from Oversight: Fire Alarms and Police Patrols Reconstructed.” Journal of Law, Economics, and Organization 10(1): 96-125.

MACEY, J. R. (1992). "Organizational Design and the Political Control of Administrative Agencies." Journal of Law, Economics, and Organization 8(1): 93.

MCCUBBINS, M. D. and T. SCHWARTZ (1984). "Congressional Oversight Overlooked: Police Patrols Versus Fire Alarms.” American Journal of Political Science 28(1): 165-179.

MCCUBBINS, M. D., R. NOLL and B. R. WEINGAST, (1987). "Adminstrative Procedures as Instruments of Political Control." Journal of Law, Economics and Organization 3: 234-277.

MCCUBBINS, M. D., R. NOLL and B. R. WEINGAST (1989). "Structure and Process, Politics and Policy:

Administrative Arrangements and Political Control of Agencies." Virginia Law Review 75: 431482.

MCCUBBINS, M. D. and T. SCHWARTZ (1984). "Congressional Oversight Overlooked: Police Patrols Versus Fire Alarms.” American Journal of Political Science 28(1): 165-179.

MUELLER, B. "Institutions for Commitment in the Brazilian Regulatory System.” The Quarterly Review of Economics and Finance. (forthcoming)

MUELLER, B. and C. PEREIRA (1999). "Testing Theories of Congressional Committee's Composition and Power: The Case of the Brazilian Congress." Third World Conference of the International Society for New Institutional Economics, Washington DC.

PELTZMAN, S. (1976). “Towards a More General Theory of Regulation.” Journal of Law and Economics 19: 211-240.

PEREIRA, C. and MUELlER, B. (2000), "Uma Teoria da Preponderância do Executivo: O Sistema de Comissões no Legislativo Brasileiro". Revista Brasileira de Ciências Sociais, 15 (43): 45-67.

PEREIRA, C.; COSTA, N. and GIOVANELLA, L. (2001). "O Jogo da Saúde Suplementar no Brasil: 
Análise dos Interesses e do Processo Decisório na Arena Legislativa.” Novos Estudos CEBRAP (forthcoming).

PEREIRA, C. (2000). What are the Conditions for the Presidential Success in the Legislative Arena? The Brazilian Electoral Connection. Ph.D. Dissertation defended in the Department of Political Science at the New School University.

PEREIRA, C. and RENNÓ, L. (2001). "O que é que o reeleito tem? Dinâmica Política Local e nacioNal nas Eleições de 1998 para a Câmara Dos Deputados”. Dados Vol 44(2): 323-362.

PINTO, H. (2001). “A Comparative Analysis of Energy Regulatory Agencies in Brazil.” Paper presented at the conference Competition and Regulation: The Energy Sector in Brazil and UK/EU, Centre for Brazilian Studies, Oxford.

PRZEWORSKI, A. (1998). “The State and the Citizen.” Paper prepared for the International Seminar on Society and the Reform of the State, Sao Paulo, Brazil, March 26-28, 1998.

SAVEDOFF, W.D. and P.T. SPILLER, 1999, Spilled Water, Washington D.C., Inter-American Development Bank.

SPILLER, P. T. (1990). "Politicians, Interest Groups, and Regulators - a Multiple-Principals Agency Theory of Regulation, or "let them be bribed".” Journal of Law and Economics.1: 65-101.

SPILLER, P. T. and E. H. TILLER (1997). "Decision Costs and the Strategic Design of Administrative Process and Judicial Review." Journal of Legal Studies XXVI(June).

STIGLER, G. (1971). “The Theory of Economic Regulation.” Bell Journal of Economics 2(Spring): 321.

WEINGAST, B. R. (1984). “The Congressional-bureaucratic System: a Principal Agent Perspective (with applications to the SEC).” Public Choice 44(1): 147-191. 


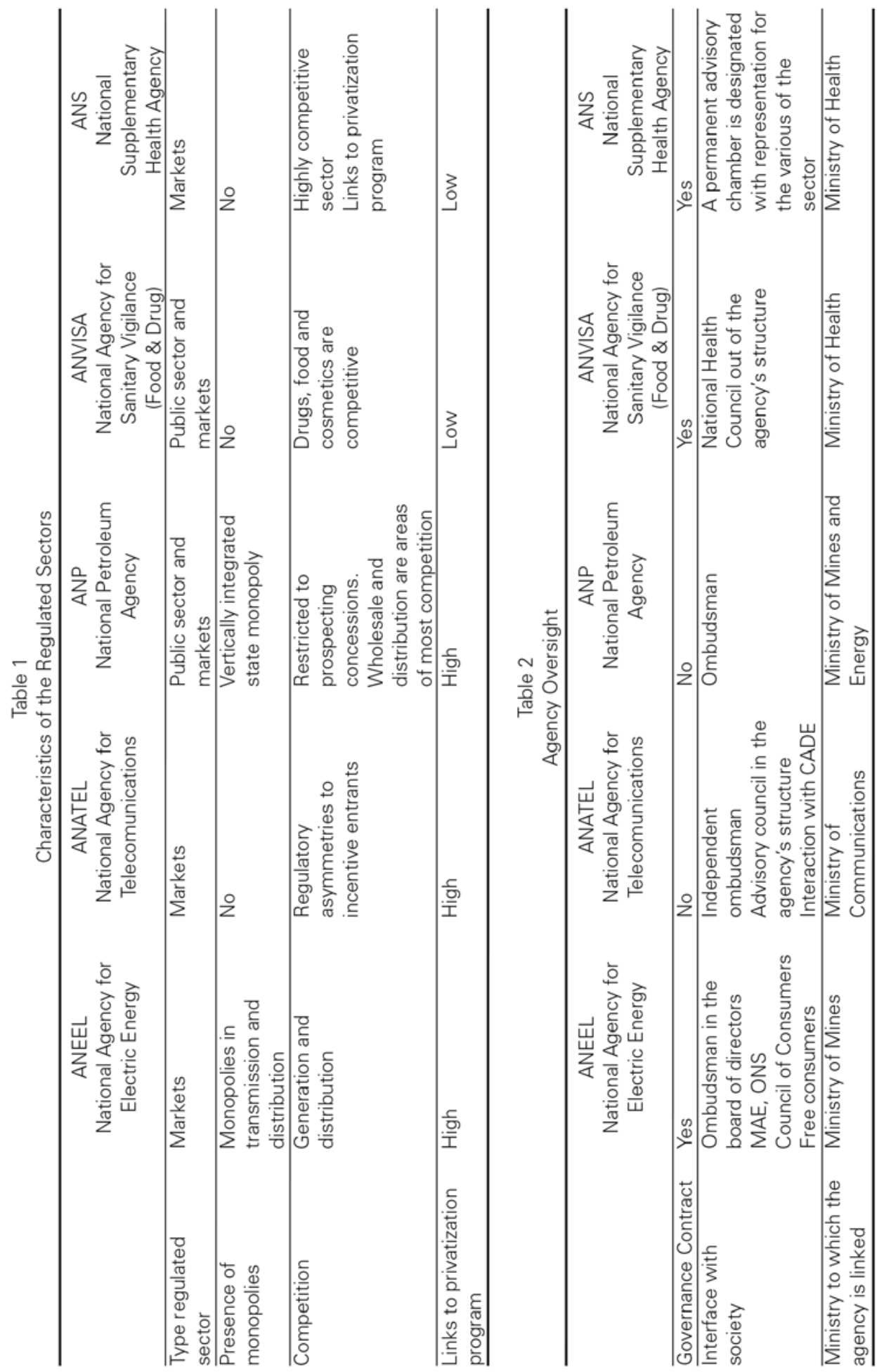



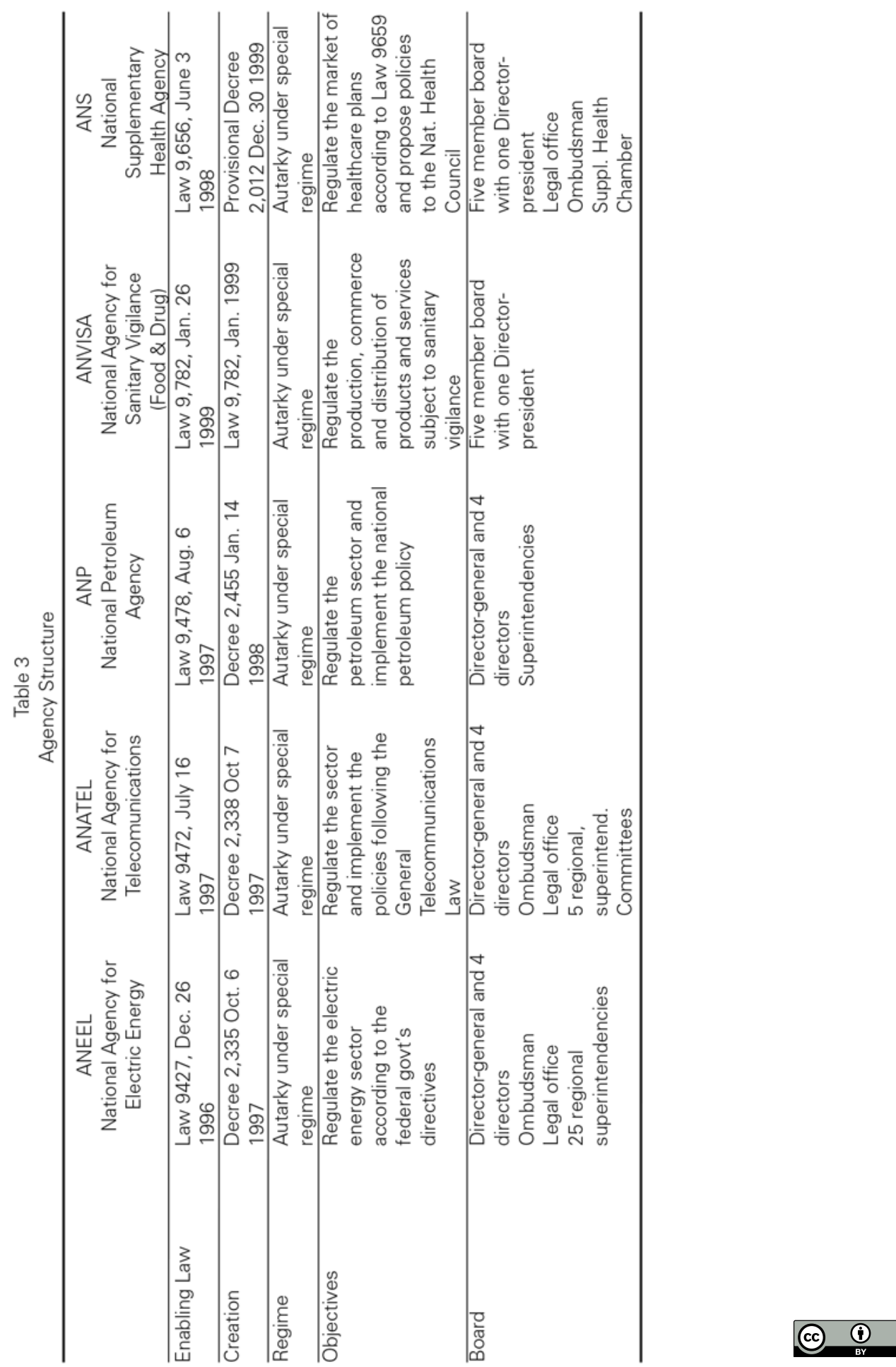